Mina Bogosavljević Jovanović1, Zoran Radojičićc

${ }^{1}$ Faculty of Economics, Finance and Administration, Belgrade, Serbia

${ }^{2}$ University of Belgrade, Faculty of Organizational Sciences, Serbia

\title{
Consumer Behaviour in the New Products Management in Serbia
}

UDC: 005:.346:005.936.43

658.8

DOI: 10.7595/management.fon.2016.0012

\begin{abstract}
Initiating the process of new product development based on consumer needs and by satisfying their expectations, as required by the concept of marketing, emphasizes indubitable significance and contribution of consumer behaviour in marketing. However, insufficient or inadequate application and understanding of the consumer has been observed in the practice, in the process of innovation. Therefore, managers of the two companies that were involved in the process of new instant coffee development were interviewed. Secondary data, concerning the brand performance are data of the longitudinal studies of market research agencies. The paper shows that insufficient attention paid to consumers in the new product development impacts the success of the product. It has been confirmed that the marketing managers rely on consumer behaviour and that they are aware of its importance, but use it quite superficially. The conclusion is that, in practice, enterprises in Serbia, in addition to the insufficient application of consumer behaviour in the new products development, face the shortcomings related to the process itself, such as the lack of marketing concept acceptance, production of certain formal documents, strategic planning as well as consumer research. The paper proposes a modification of the new products development model that insists on the four observed shortcomings.
\end{abstract}

Keywords: consumer behaviour, product management, the new product development, innovation, market, protocol, concept

\section{Introduction}

The aim of this paper is to investigate the application of consumer behaviour in marketing management, in the field of new products development. Research on the interface of innovation and branding is limited. Managers receive little guidance regarding how consumers' perceptions of a brand's innovativeness affect firm performance metrics such as consumer brand loyalty. Research examining linkages between innovativeness and customer satisfaction is considered critical (Pappu, Quester, 2015).

Two large manufacturers of black coffee in Serbia have entered, at the same time, the segment of instant coffee, where the multinational manufacturers dominate. As it is a hazardous step, it is interesting to show how those manufacturers have prepared to launch new products on the market, intended for completely different target group of consumers than they are familiar with. This paper will display the information about the success of the conducted innovations by market volume share, brand recognition, as well as the degree of the managers' satisfaction with the achievements. The main objective of Behavioural Decision Theory (BDT) research, demonstrating that economic theory often fails is a description of decision making as well as gaining insights into systematic influences on judgment and choice (Simonson, I., 2015).

The practical goal of this research is to advance future new products development, to achieve better product performance as well as higher consumer satisfaction. 


\section{Marketing Management}

Some economists' interests for the material factors is the same as the amount of psychologists' 'negligence for the economic behaviour of individuals". (llic, 2011, p.11; Petrović, 2007). Based on the interdisciplinary knowledge of marketing and psychology, a new scientific discipline has been developed (Maričić, 2005; Milas, 2007, Živković, 2014) or a new marketing branch (Schiffman \& Kanuk, 2009; Begen, 2004; Hoyer \& Maclnnis, 2004) - the consumers' behaviour. There is a growing importance in consumer behaviour even in e-commerce (Čavoški \& Markovic, 2015). The more the business performs according to the concept of marketing, forcing enterprises to be focused on the market and not on the product itself, the more the consumer is included (Joksimovic, 2013). Consumers often make product choices that involve the consideration of money and time. A scientific approach to understanding consumer behaviour appears to be lacking in many corporate research surroundings (Dijksterhuis, 2016). Building dual-process models, the two essential resources activate qualitatively different modes of processing: while money is processed analytically, time is processed more affectively (Lee L. et al., 2015).

What is necessary for the market orientation and marketing concept is "the superior expertise in understanding, satisfying and maintaining the consumer" (Mllisavljevic, 2006, p.7). The problem is, according to Foxal, Goldsmith \& Brown (2007), that not many manufacturers are ready to accept the marketing concept. It can be said that there is a chain market focus - innovation - success, while Milutinović, Stošić \& Mihić (2015) define a concept of strategic innovation as the key to competitiveness.

\subsection{Marketing Management Through "the Consumer" Frame}

Marketing is often accused of creating false wishes and support materialism, through greedy ambition and creation of the wrong value system (Hrnjica, 2005). Many believe that the profound understanding of consumers' behaviour, actually contributes and facilitates unethical marketing exploiting a human weakness (Schiffman \& Kanuk, 2009). Likewise, marketing is often accused of the development of materialism (Hrnjica, 2005), for the decrease of social values (Rotfield, 2005), and for preoccupation with creating money and exaggerated purchase (Roberts\& Manolis, 2000). Lange at al. (2015) researched the impact of information on liking and willingness to pay. They were asked to indicate the maximum price they would pay for each product. The returns of customer participation on new product development performance can vary substantially in systematic and empirical integration of a customer participation (Chang, Taylor, 2016).

In the definition of marketing, there are two psychological phenomena - the need and the want, which marketing vaguely defines, and it seems that not even psychology separates them from the other motivational factors. When described, the needs and the wants of the target group are satisfied through the marketing mix elements which the company can control (Kotler et al., 2007), that have a psychological dimension as well (Begen, 2004; Milas, 2007). Modern marketing mix takes care of long-term communication, trying to establish a stronger emotional connection with a consumer (Jankovic, 2012). Furthermore, advanced segmentation relies on psychographic measurements more than just demographic (Bogosavljević, 2001). A study done by Marković, Antanasijević \& Ninković (2011) emphasizes statistically important differences between psychographic segments based on their affective and cognitive relation to money. The latest research has shown that information, price, or moral influence has an impact on an ethical consumption and are important (Andorfer, Liebe, 2015).

\subsection{The Consumer Through Marketing Management Frame}

Besides the influence of external factors, consumer and their effects, cognition and behaviour, also depend on many interior factors, such as experience, learning, motivation, perception, memory and others.

- Motivation-"To understand consumers' motives presents half of job done so that their needs are adequately satisfied which leads to purchase and the profit to the enterprise." (Maričić, 2005, p. 87).

- Perception- The function of perception is to defend the organism from too many stimuli (Hrnjica, 2005), and it can be of use for the efforts of marketing if well understood. Therefore, it is necessary to comprehend the characteristics of perception, such as perception intensity, subliminal perception, the selectivity of perception, perception integrity, generalizing of perception and 
adaptation stimulus, to understand the influence of perception on the consumer behaviour as well as the notions: perceptive map and perception of risk. The causal role of the specific emotions in risk perception has been confirmed (Drače \& Ric, 2012).

- Memory and learning- In marketing, the cognitive approach to learning is very helpful (the consumer is being treated as a person who actively and understandingly solves the problems and tries, in a certain way, to influence the environment (Maričić, 2005; Milas, 2007)). It is especially useful in the new products development, having to satisfy newly created needs and wants of the consumer without previous experience (Maričić, 2005). Milutinović \& Stošić (2013) find it even more difficult in new service development projects.

- Personality, values, and lifestyle- Personality and personality traits are important market demand factors because they influence the type and the brand of the purchased product.Therefore, there is a possibility of using personality traits as a guideline for marketing activity, such as the creation of new brands according to preferences of innovative consumers or old brands repositioning throughout the psychographic segmentation of the market (Elliot \&Ynnopoulou, 2007; McDonald \& Alpert, 2007). The usage of lifestyle parameters in marketing is more commonly used, as a "syndrome of interconnected personality traits, attitudes, and value." (Milas, 2007, p.128).

\subsection{The New Product in the Area of Marketing Management}

New products are developed considering the importance of the entire organization's functioning and its sustainability on the market. It is necessary for the experts in this field to know all the aspects of marketing and the whole business decision-making process. The innovation is the main characteristic of the successful marketing strategies; it is the "lifeline of every organization" (Foxall et al., 2007, p.10; Milas, 2007; Crawford \& Benedetto, 2000). Innovation is important for small and medium enterprises as well, as it affects their ability to grow (Veselinova, Gogova Samonikov, 2012). The distinction between the short term and the long term is especially critical for radical innovations that create a completely new product category (Gatignon, Gotteland,Haon, 2016).

Crawford \& Benedetto (2000) explain the new product development process through five consecutive but overlapping phases: identification and selection of opportunities, concept development, evaluation of ideas and projects, development and commercialization. The process of accepting a new product is not automatic and should be considered as a macro process (how does an innovation spread throughout society) and micro process (the phases that the individual goes through before accepting something) (Kotler et al., 2007; Crawford \& Benedetto, 2000).

Although Bulut, Trifunović and Zivaljević (2011) conclude that Serbian manufacturers consider their consumers' dissatisfaction as a primary signal that launches innovation, other authors used the conceptual model to test in two empirical studies for three global consumer electronics brands in two product categories (Pappu, 2016).

Kucia \& Szymura-Tyc (2012) state that in transition societies, a major role in decision making in the innovation process is assigned to directors and board of directors instead of being given to the marketing department, with a reduced consumers' role. Serbia has progressed a lot in the past years, both in education and expertise of managers, as well as in professional approach, but the business decisions are still often made by using intuition or under the authority of the owner or the board of directors. The new product development can only get more complex and more challenging in the future as the fierce competition leads to increasing market fragmentation. An exploration of consumer attitudes and purchasing patterns are one of the necessary steps in developing a new product (Winchester M., Arding R., Nenycz-Thiel M., 2015).

\section{The Method}

The first part of the research refers to the analysis of the secondary data about the brand success (market share, value share, brand recognition, brand loyalty). The data came from the studies done by independent market research agencies: AC Nielsen (retail audit) and Ipsos Strategic Marketing (a longitudinal study of brand success and image, BrandPulse). 
The second part of the research consists of interviews with managers who participated in the development of the new brand A and brand B. The study was conducted in Belgrade, during February and March 2015; by using qualitative methodology (quantification is possible only for a couple of questions). The unstructured interview was the most suitable, because of the expectation of the social, i.e., business adequate answers. For better insight and confirmation of the interview, a partial quantification was also conducted through a structured questionnaire, by using a Likert scale. This instrument was given to the respondents during the interview.

\subsection{The Coffee Market in Serbia in Time of New Products Launch}

During 2006, black coffee consumption was still over $90 \%$ of overall coffee consumption in Serbia. The volume share growth of instant coffee has been noted in a segment named "mixes," which is instant coffee with milk, sugar or different flavours (as "2 in 1", " 3 in 1", "cappuccino" and additions to coffee like chocolate, vanilla, banana, rum). On the other hand, in developed countries, more important and the basic instant coffee segment is a segment of pure soluble instant coffee, which is mixed with coffee and milk during the preparation.

The basic instant coffee market, a portion of pure, soluble coffee, was divided between the two multinational manufacturers (Nestle and Jacobs). The two new products (brand A and brand B), have soon after launch, in 2007 , reached $14 \%$ of market share, which is a great success (brand A $11 \%$ and brand B $3 \%$ ). The segment named "mixes" is the most fragmented segment, in which Nescafe is the leader but is not as dominant as it is in the previously mentioned segment. New products - brands $A$ and $B$ are reaching an unbelievable $23 \%$ of market share (brand A $20 \%$, brand B 3\%) soon after launch. The favorable perception of these two dominant manufacturers of black coffee in the Serbian market has positively influenced their entrance to the segment of instant coffee, and it is expected that this positive image should influence the new product acceptance, contributing, seven years later, to good, long-lasting business.

\section{The Results}

The AC Nielsen retail audit data show that the black coffee market share, although still dominant, is continuing to decrease while the proportion of the instant coffee segment is increasing. Comparing the retail audit data from 2007 and seven years later (in 2014), in the first stage of market appearance, a significant market share loss, and almost no existence was recorded. In the segment of pure soluble coffee, brand $A$ loses, while in „mixes“ brand B loses share and brand A stagnates.

Table 1: New products market share in Instant coffee segments in 2007 and 2014

\begin{tabular}{crr} 
Pure, soluble coffee & 2007 & 2014 \\
\hline Brand A & $3 \%$ & $0.5 \%$ \\
Brand B & $11 \%$ & $0.1 \%$ \\
Coffee mixes & 2007 & 2014 \\
\hline Brand A & $20 \%$ & $16.5 \%$ \\
Brand B & $3 \%$ & $4.0 \%$
\end{tabular}

Source: Retail Audit AC Nielsen

Analyzing brand strength position within the competition, i.e., in the consumers' minds, both manufacturers completely disappear in 2014 in a pure, soluble coffee segment, and in "mixes" segment they are losing one level each. 
Table 2: New products position in Instant coffee segments in 2007 and 2014

\begin{tabular}{crr} 
Pure, soluble coffee & 2011 & 2014 \\
\hline Brand A & 4 & $/$ \\
Brand B & 3 & $/$ \\
Coffee mixes & 2011 & 2014 \\
\hline Brand A & 2 & 3 \\
Brand B & 3 & 4
\end{tabular}

Source: Brand Pulse (Ipsos Strategic Marketing)

While Nescafe consumers use other brands in more than a half of the instant coffee consumption, Jacobs's consumers are quite loyal. The cross usage data are important because they show that the brand $A$ and brand B make the worst competition to each other, in the "mixes" segment.

Table 3: The cross use of the brand of the "mixes" coffee segment

\begin{tabular}{lrrrr} 
& $\begin{array}{r}\text { Nescafe } \\
\text { 3in1/2in1 }\end{array}$ & $\begin{array}{r}\text { Jacobs } \\
\text { 3in1/2in1 }\end{array}$ & $\begin{array}{r}\text { Brand A } \\
\text { 3in1/2in1 }\end{array}$ & $\begin{array}{r}\text { Brand B } \\
\text { 2in1/3in1 }\end{array}$ \\
\hline Nescafe 3in1/2in1 & 100.00 & 75.12 & 68.48 & 69.31 \\
\hline Jacobs 3in1/2in1 & 40.23 & 100.00 & 46.95 & 46.50 \\
\hline Brand A 3in1/2in1 & 29.19 & 37.37 & 100.00 & $\mathbf{5 7 . 4 2}$ \\
\hline Brand B 2in1/3in1 & 21.61 & 27.08 & $\mathbf{4 2 . 0 0}$ & 100.00 \\
\hline
\end{tabular}

Source: BrandPulse, Ipsos Strategic Marketing

\subsection{The Results of the Primary Research}

The interviewed managers stated that the two companies have had a goal, by the development of brand $\mathrm{A}$ and brand $B$, to make a presence in the growing segment of instant coffee in Serbia, only by having a proper distribution and lower price than the leader, Nescafe, but without a strong competitive strategy. By that time, everyone was satisfied with the achievement, but now all the interviewed managers state that the approach to the process could have been more ambitious with a possibility of getting closer to the leader or even acquiring its position. The other goal that these enterprises had by developing the new instant coffee products, which are more modern drinks and have consumers in the younger age group, was to rejuvenate the image of black coffee brands. Unfortunately, the conclusion is that the transfer was vice versa - the strong image of the black coffee brands has been transferred to the instant coffee brands, and, on the other hand, the strength of the corporate image has not been exploited enough. The competitive advantage was that they could compare to the multinational brands, where it is a fact that they are produced by known, reliable and domestic black coffee manufacturer, which was not used adequately in the sense of transferring positive attributes that come with the positive image of the maker but with the independence from the picture of the black coffee brands. Furthermore, both enterprises have not defined their targeting and positioning strategies but have imitated the approach of the category leader, Nescafe, which was too far from the corporate image of these enterprises.

The initiative for the idea of these new products development are the global trends, and that has been stated as a first stage by all interviewed managers. In general, stages of this process, as revealed by this research, are similar and somewhat match the theoretical model. 
Table 4: The stages of new product development

\begin{tabular}{ccc} 
Stage & Brand A & Brand B \\
\hline 1 & idea, trends & idea, trends \\
2 & financial projections & strategical and tactical research \\
3 & concept development & development of 4Ps \\
4 & tactical research & financial projections \\
5 & launch & launch \\
6 & evaluation & evaluation
\end{tabular}

However, none of the managers have mentioned the formal documents which are imposed by the new product development theory, such as:

- The Product Innovation Charter (PIC), which formalizes the reasons for opportunities search, as well as the goals that need to be achieved, with certain rules.

- The product concept in consumers terms, by listing the attributes and perceptive gap analysis.

- The product protocol (the products' essence and its benefits) which has the description of the target group, the positioning, the product attributes, timeline planning as well as marketing and financial demands.

The consumer is mentioned only in the context of market research, which is classified in one phase. The analysis of the consumer needs, as the theory of marketing and new product development impose, has been conducted only in a sense of global trends analysis. All the managers spontaneously point out the marketing research as an important factor. However, the conclusion is that managers mention only tactical research (testing the flavour, design or price) and that the investigation into the consumers' needs, habits, attitudes, segmentation or perceptive maps has not been carried out before the launch. The consumer was considered as an important factor during these new products development, not as a person with his dynamics and processes, but rather as a group of reactive consumers. During the new products development and marketing management, all of the surveyed executives note that the consumer's role is vital, but during the application, the following factors diminish this importance:

- The executive's attitude that the consumers' opinions and wishes should be taken with caution, and rely on business intuition, because sometimes consumers do not know what they need.

- The executive's attitude that "they do not want to stand out and slow down the processes by pointing out the soft process elements". The hard process elements of the new product development are material, visible, such as the creation of the product itself, its listing, financial postulates, etc.

- Performance evaluation of employees, which is based on time. By pointing out the soft elements, managers could be treated as ones that complicate and slow down the process, which is undesirable.

Sorting the analysis by relevance during any new product development, and from the present point of view, the interviewed managers state the consumers' analysis as the most important one. The next one is the competition analysis, which leads to the market analysis as the most important one.

Table 5: Relevance of the analysisduring the new products development

\begin{tabular}{clc} 
relevance rank & \multicolumn{1}{c}{ analysis } & average score \\
\hline 1. & consumers analysis & 2.7 \\
2. & competition analysis & 2.9 \\
3. & production analysis & 3.0 \\
4. & macro analysis & 3.2 \\
5. & financial analysis & 3.6 \\
6. & human resources analysis & 5.7
\end{tabular}


The executives of both enterprises state that the management concept of their companies was far from the idea of marketing; it rather was the product concept. Furthermore, they state that their enterprises wanted to satisfy the enterprises' needs by developing new brands of instant coffee and not the consumers' needs. By analyzing the launching strategy of the two new brands, it seems that even the fundamental postulates of marketing management were not adequately implemented.

- The competitive advantage, the fact that they were created by the domestic, known and reliable Turkish coffee producer, was not exploited properly.

- The differentiation between the new competitive products has not been implemented, which is confirmed in several data sources, in this paper.

- Neither of the new products had their positioning and targeting strategy but imitated the strategy of the category leader, which is too far from their corporate image.

- The communication strategy, although different, did not fulfill the consumers' expectations

- The development stages of two new products correspond somewhat to the theoretical model but without the use of the formal documents, as the new product development theory imposes.

- The managers of the both enterprises state that the management concept of their businesses was at that time far from the marketing idea, but rather a product concept.

For the well-being of the individual as well as of the society, it would be desirable to get close to social marketing concept during the new product development, but in Serbia, it seems that only sporadic socially responsible activities exist at the enterprise level, not at the brand level. It appears that the enterprises in Serbia are still moving towards the marketing concept, which is a lower stage than a social marketing concept. Although entire marketing literature points out the importance of the marketing concept in marketing management, this concept is even more important during the new products development.

\subsection{The New Product Development Model}

The suggested model of the new product development is the revised model developed by Crawford \& Benedetto (2000). The modification is based on pointing out the four shortcomings, identified in this research, and those are acceptance of the marketing concept, the formal documents creation, and the application of strategic planning and consumers researching - from the initial idea to the product development. The primary criteria for the division into phases are formal documents which need to be created.

- Phase 1. Product Innovation Charter. In the starting, first phase, it is necessary to create a document that describes the reasons for the search of new opportunities and ideas. It is important to define clearly and agree on the goal/goals of the new product development, within the enterprise.

- Phase2. Product concept. The product concept is a document that formalizes the idea and the opportunity, by describing them thoroughly, in the consumer sense, and by demanding extensive market research and analysis to answer the following questions: What does the consumer need? Which technology can make that happen? How do we solve the problem/the need for the consumer? Which attributes does the product have? Where is the product expected to be found on the consumers' perceptive map (by analyzing the perceptive gap)?

- Phase 3. The result of the concept is testing. The document which contains the result of the concept testing demands a previous concept testing on a small target group of the consumers, and further improving and adapting of the product to the consumers perception of the benefit the product brings.

- Phase 4. The product protocol. The product protocol explains the essence of the new product, i.e., what is the advantage of it for the consumer, with the descriptions of the decisions that came from the strategic analysis and planning -the description of the target group, the positioning and the attributes of the product. 
This paper investigates whether the consumer was treated with the necessary knowledge, understanding and appreciation of the new product developments. As an example, two new instant coffee products have been used, which have been launched at the same time by the two large black coffee manufacturers on the Serbian market, in 2007.

The success of two new products, as well as the satisfaction of the final consumers, is reflected in the data of the independent research agencies. Comparing the data in a first stage of launching, and seven years later (2014), a significant market share decline of both new products can be recognized. The brand strength and the competition showed that both manufacturers are losing their positions. The secondary data indicate that the two new products have not made nor retained the market success. However, the existence of a severe competition between the two new products, as well as strong multinational competition can be noticed in the data.

By examining the process of the new products development in practice, the observed insufficient or inadequate application of consumers' orientation during the new product development in Serbia is confirmed in this paper. The reason for that is in the incomplete acceptance of the marketing concept, as well as in the overall corporate culture and in the attitudes of the managers themselves. Homburg et al. (2015) indicate that the design dimensions positively influence willingness to pay and also have a positive effect on purchase intention and word-of-mouth, both directly and indirectly, through brand attitude. Prior research has posited that product attributes are primary drivers of success that a firm must consider when developing a competitive advantage (Li G., Zhang R., Wang C., 2014)

In general, during a new product development, all of the interviewed managers state that the role of the consumer is crucial, but that their wishes should be taken with caution because sometimes the consumers do not know what they need. The consumer behaviour is crucial to the managers, but they point out that they do not want to "stand out and slow down the processes by implying those soft process elements". Van Loo et al. (2015), in their research about consumer preferences, willingness-to-pay and visual attention, showed a sustainability of customers.

The main factor for that is not the lack of managers' education or the literature but, for the most part, performance evaluation of employees, which is based on time. Although Bulut and associates (2011) state that the Serbian manufacturers consider the consumers' dissatisfaction as the primary signal to start the innovation, this paper did not confirm that. Serbian coffee manufacturers did not launch the new products development because of the consumers' dissatisfaction, but because of the perceived threat of the growing instant coffee segment. The surveyed managers often mentioned the influence of the owner and the board of directors, as Kucia\&Szimura-Tyc (2012) point out that it is often the case. Cvetanović, Nedić and Despotović (2013) point out that it is precisely a small innovation what causes a lack of competitiveness of the Serbian economy.

The paper concludes that, in practice, enterprises in Serbia, in addition to the insufficient application of consumer behaviour in the new product development, face shortcomings related to themselves - such as the lack of marketing concept acceptance, production of certain formal documents, and strategic planning as well as consumer research. A modification of a new product development model is therefore proposed, aiming to overcome the four observed shortcomings by mandating the creation of formal documents in various phases of product development, which requires consumer research and strategic planning, ensuring respect for the modern concept of marketing. 


\section{REFERENCES}

[1] Andorfer V.A., Liebe U. (2015). Do information, price, or morals influence ethical consumption? A natural field experiment and customer survey on the purchase of Fair Trade coffee, Social Science Research, Volume 52, July 2015, Pages 330-350

[2] Begen F. (2004). Psihologija umarketingu, Clio, Beograd

[3] Bogosavljević M. (2001). Ponašanje potrošača i životni stilovimladih Jugoslovena, Diplomski rad, Filozofski fakultet, Beograd

[4] Bulut I., Trifunović D., Živaljević A.(2011). Customer satisfaction as a driving force for product or service innovation in Serbian companies, Strengthening the Competitiveness and Economy Bonding of historical Banat, Megatrend Univerity, Beograd

[5] Crawford C.M., Benedetto C.A. (2000). New Products Management, McGraw - Hill

[6] Cvetanović S., Nedić V., Despotović D. (2013). Niska inovativnostkaouzroknekonkurentnostisrpskeprivrede, Ekonomika, 2, 1-9.

[7] Čavoški S., Marković A. (2016). Analysis of Customer Behaviour and Online Retailers Strategies Using the Agent - Based Simulation, Management, 77, 13-24 DOI: 10.7595/management.fon.2015.0031

[8] Chang W., Taylor S. A. (2016) The Effectiveness of Customer Participation in New Product Development: A Meta-Analysis. Journal of Marketing: January 2016, Vol. 80, No. 1, pp. 47-64. doi: http://dx.doi.org/10.1509/jm.14.0057

[9] Dijksterhuis G. (2016). New product failure: Five potential sources discussed, Trends in Food Science \& Technology, Volume 50, April 2016, Pages 243-248, doi:10.1016/j.tifs.2016.01.016

[10] Drače S., Ric F. (2012). The effect of emotions on risk perception: Experimental evaluation of the affective tendencies framework, Psihologija, 45, 4, 409-416 DOI: 10.2298/PSI1204409D

[11] Elliott R., Yannopoulou N. (2007). The nature of trust in brands:a psychosocial model, European Journal of Marketing, 41, 9/10, 988-998 DOI 10.1108/03090560710773309

[12] Foxal G.R., Goldsmith R. E., Brown S. (2007). Psihologija potrošnje umarketingu, Naklada Slap, Zagreb

[13] Gatignon H., Gotteland D., Haon C., (2016). Making Innovation Last: Volume 2. Sustainable Strategies for Long Term Growth, Palgrave Macmillan UK, Print ISBN: 978-1-349-56543-6, DOI: 10.1007/978-1137-57264-6.

[14] Homburg C., Schwemmle M., Kuehnl C. (2015) New Product Design: Concept, Measurement, and Consequences. Journal of Marketing: May 2015, Vol. 79, No. 3, pp. 41-56. doi: http://dx.doi.org/10.1509/jm.14.0199

[15] Hoyer W.D., MacInnis D.J. (2004). Consumer Behaviour, Houghton Mifflin Company, Boston

[16] Hrnjica S. (2005). Opšta psihologija sa psihologijom ličnosti, Naučna knjiga nova, Beograd

[17] Ilić S. (2011). Ekonomska psihologija, Feniks Libris, Beograd

[18] Janković M. (2012). Integrated Marketing Communications and Brand Identity Development, Management, 63, 91-100DOI: 10.7595/management.fon.2012.0015

[19] Joksimović I. (2013). Strategijsko upravljanje brendom na osnovu marketing i finansijskih indikatora, Doktorska disertacija, Fakultet Organizacionih nauka, Beograd

[20] Kotler P., Vong V., Sonders DŽ., Armstrong G. (2007).Principi Marketinga, 4. izdanje, Mate, Beograd

[21] Kucia M., Szimura - Tyc M. (2012) The Role of Marketing in Innovation Processes in a Transition Economy, $3^{\text {rd }}$ EMAC CEE Regional Conference: Marketing Theory Challenges in Emerging Societies, 231-237, Centar za izdavačku delatnost Ekonomskog fakulteta Univerziteta, Beograd

[22] Lange C., Combrisd P., Issanchoua S., Schlicha, P. (2015). Impact of information and in-home sensory exposure on liking and willingness to pay: The beginning of Fairtrade labeled coffee in France, Food Research International, Volume 76, Part 3, October 2015, Pages 317-324

[23] Lee L., Lee P. M., Bertini M., Zauberman G., Ariely D. (2015). Money, Time, and the Stability of Consumer Preferences. Journal of Marketing Research: April 2015, Vol. 52, No. 2, pp. 184-199. doi: http://dx.doi.org/10.1509/jmr.10.0386

[24] Li G., Zhang R., Wang C. (2014). The Role of Product Originality, Usefulness and Motivated Consumer Innovativeness in New Product Adoption Intentions, J PROD INNOV MANAG 2015;32(2):214-223. DOI: 10.1111/jpim.12169

[25] Maričić B. (2005). Ponašanje potrošača, Ekonomski Fakultet, Beograd

[26] Marković Z., Antanasijević I., Ninković B.(2011). The Relation to the Money as a Factor of the Consumer Behaviour, Management, 62, 111-121 DOI: 10.7595/management.fon.2011.0004

[27] Mc Donald H., Alpert F. (2007). Who are "innovators" and do they matter?, Marketing Intelligence \& Planning, 25, 5, 421 - 435 
[28] Milas G. (2007). Psihologija marketinga, Target, Zagreb

[29] Milutinović R., Stošić B. (2013). Key Elements of Innovation Project Management in Services, Management, vol 69, 65 - 73 DOI: 10.7595/management.fon.2013.0027

[30] Milutinović R., Stošić B., Mihić M. (2016). Concepts and Importance of Strategic Innovation in SMEs: Evidence from Serbia, Management, vol 77, 35-42 DOI: 10.7595/management.fon.2015.0030

[31] Milisavljević M. (2006).Strategijski marketing, Ekonomski fakultet, Beograd

[32] Pappu R., Quester G. P., (2016). "How does brand innovativeness affect brand loyalty?", European Journal of Marketing, Vol. 50 Iss: 1/2, pp.2 - 28, DOI: http://dx.doi.org/10.1108/EJM-01-2014-0020

[33] Pappu R., Quester P. (2015). Looking Forward, Looking Back: Drawing on the Past to Shape the Future of Marketing. Brand Innovativeness Effects on Perceived Quality, Satisfaction and Loyalty, Proceedings of the 2013 World Marketing Congress, Session 10.7., p 763, Print ISBN: 978-3-319-24182-1, Academy of Marketing Science, Springer International Publishing, DOI: 10.1007/978-3-319-24184-5_185.

[34] Petrović I. (2007). Psihološki aspekti tržišne pozicije proizvoda, Doktorska disertacija, Filozof́ski fakultet, Beograd

[35] Roberts J.A., Manolis C. (2000). Baby Boomers and Busters: an exploratory investigation of Attitudes towards Marketing, Advertising, and Consumerism, Journal of Consumer Marketing, 17 / 6, 481- 499

[36] Rotfeld H.J. (2005). The cynical use of marketing to the unwitting consumer, Journal of Consumer Marketing,22/2, 60 - 61 DOI 10.1108/07363760510595931

[37] Schiffman L.G., Kanuk L.L.(2009).Consumer Behaviour, $10^{\text {th }}$, Prentice Hall

[38] Simonson I. (2015). Mission (Largely) Accomplished: What's Next for Consumer BDT-JDM Researchers?, Journal of Marketing Behaviour, 2015, 1: 9-35. ISSN 2326-568X; DOI $10.1561 / 107.00000001$

[39] Van Loo J.E., Caputo V., Nayga M.R., Seo H.S., Zhang B., Verbekea W. (2015). Sustainability labels on coffee: Consumer preferences, willingness-to-pay and visual attention to attributes, Ecological Economics, Volume 118, October 2015, Pages 215-225

[40] Veselinova E., Gogova Samonikov M., (2012). SMEs Innovationand Growth in EU, Management, 64, 8794 DOI: 10.7595/management.fon.2012.0022

[41] Winchester M., Arding R., Nenycz-Thiel M. (2015). An Exploration of Consumer Attitudes and Purchasing Patterns in Fair Trade Coffee and Tea, Journal of Food Products Marketing, Volume 21, Issue 5, 2015 , p. 552-567, DOI: 10.1080/10454446.2015.1041197

[42] Živković R. (2014). Ponašanje potrošača, Univerzitet Singidunum, Beograd

Receieved: March 2016. Accepted: May 2016.

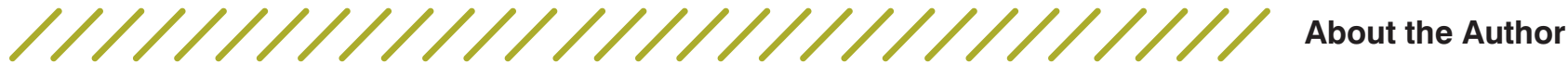

Mina Bogosavljević Jovanović FEFA - Faculty of Economics, Finance, and Administration, Beograd mina.bog.jov@gmail.com

Graduated in Psychology at the University of Belgrade and holds a Msc in Marketing, from the University of Sheffield. She is finishing her PhD studies at the FEFA. Mina is an experienced marketing research and strategic planning practitioner, through management positions in The Coca Cola Company, Grand kafa, Ipsos Strategic Marketing and Atlantic group.

\section{Zoran Radojičić \\ Faculty of Organizational Sciences, Univeristy of Belgrade zoran@fon.bg.ac.rs}

Full professor at the Faculty of Organizational Sciences in Belgrade. He teaches several subjects in the field of statistics at the University of Belgrade and the University of Novi Sad. Head of the Laboratory of Statistics on the basic faculty and member of the

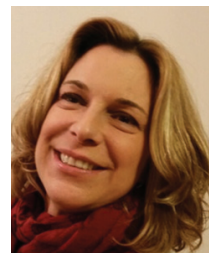
Department of Operations Research and Statistics. 